\title{
Equipping small business retailers to manage logistical supply chain drivers: A theoretical guideline
}

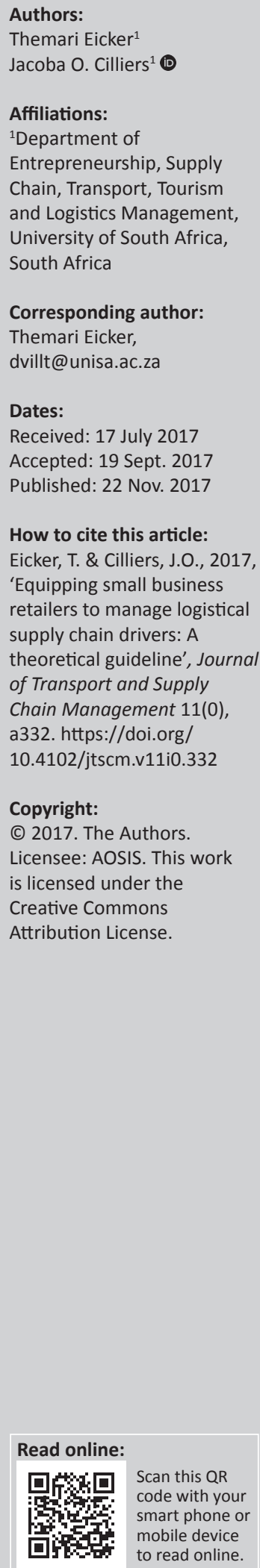

Background: Small businesses are seen as the impetus behind a country's economic growth. The South African government's continued commitment to prioritise the development of small businesses, the promising rise of the retail sector in South Africa and the substantial contribution of small businesses to trade, business services, personal services and construction make the small retailers a force to be reckoned with. Businesses often fail because of a lack of strategic fit between the competitive and supply chain strategies. It is imperative that the supply chain design, resources and processes provide the necessary capabilities to support the desired competitive strategy. Managing the three logistical supply chain drivers of facilities, inventory and transportation can contribute to achieving a strategic fit between the selected competitive strategy and supply chain strategy. The logistical supply chain drivers should not only be managed as a cohesive unit, but should also be aligned with the orientation of the selected supply chain strategy, in terms of responsiveness and cost-efficiency.

Objective: The objective of this article is to provide guidelines from literature that small business retailers can use in managing their logistical supply chain drivers to be aligned with the orientation of their selected supply chain strategy in terms of responsiveness and cost-efficiency.

Method: An extensive literature review was conducted pertaining to the management of the three logistical supply chain drivers by small retailers.

Results: It was determined that small responsive retailers typically order inventory on a frequent basis, hold excess inventory, provide customers with a seamless in-store experience and are located close to their customers. These responsive retailers make use of direct delivery from suppliers (and to customers) to increase their flexibility and reduce lead times. On the other hand, small cost-efficient retailers typically do not hold excess inventory, and their stores are usually located further away from customers. These cost-efficient retailers take advantage of both economies of scale when purchasing inventory and economies of distance when transporting inventory.

Conclusion: Literature guidelines with regard to the management of the logistical supply chain drivers are provided to assist small retailers in achieving a strategic fit between the selected competitive strategy and supply chain strategy.

\section{Introduction}

\section{Background: Small business retailers' role in South Africa's economy}

Small businesses are considered worldwide as the impetus behind income growth and prosperity for individuals and communities (Abor \& Quartey 2010:218; Aykan, Aksoylu \& Sönmez 2013:939; Katz \& Green 2012:14; Mbonyane \& Ladzani 2011:550). Nkosi, Bounds and Goldman (2013:1) state that in South Africa small businesses create employment, ensure a more equal distribution of income to citizens, promote the general economic welfare of citizens and improve local markets. Therefore, any research conducted in the field of small businesses should be encouraged because it is not only to the advantage of citizens, but also to the economic growth of a country (Nkosi et al. 2013:1; South Africa. National Planning Commission 2012).

The continued commitment to prioritise the development of small businesses by the South African government is reflected in their ambitious goal for the small business sector to create $90 \%$ of the employment opportunities within South Africa by 2030 as outlined in South Africa's National Development Plan of 2030 (South Africa. National Planning Commission 2012). This Plan further stresses the importance of supporting small businesses by encouraging both government and the

Note: This article is partially based on the first author's thesis of the degree of Master of Commerce in Business Management at the University of South Africa, South Africa, with supervisor Dr J.O. Cilliers, received October 2016, available here: http://uir.unisa.ac.za/ bitstream/handle/10500/22225/dissertation_eicker_t.pdf?isAllowed=y\&sequence=1 
private sector to procure from small businesses. Despite South African small businesses' access to ample opportunities to contribute to economic growth (South Africa. National Planning Commission 2012), a staggering $80 \%$ of small businesses regrettably tend to close down within the first 5 years of opening their doors (Strydom 2015:467; Van Eeden, Viviers \& Venter 2003:12).

South Africa forms the biggest retail market in sub-Saharan Africa, and the 20th largest in the world, with a wide array of shopping malls and retail developments (PriceWaterhouseCoopers 2012:2). Because population growth is a key driver behind economic growth, Prinsloo (2016) predicts that South Africa's positive population growth coupled with expected income growth in the higher market segments will result in retail spend to rise substantially. The promising rise of the retail sector in South Africa according to the Gauteng Quarterly Bulletin (2012:4) and the substantial contribution of small businesses to trade, business services, personal services and construction (Stats SA 2016) make the small retailers a force to be reckoned with. The crucial role of retailers in a community's economic and social welfare lies in their ability to provide consumers with choices and services (Ligthelm 2008:37). Retail intermediaries, as the final businesses in a supply chain linking manufacturers to consumers, perform vital value-adding activities according to customers' need for convenience (Prinsloo 2016:1). In an ideal customer-driven supply chain, successful retailers know the exact level of service that the customer expects at a minimal cost. They also understand what customers view as important and what level of service they are willing to pay a premium for (Allen 2012:330). In their efforts to effectively participate in a supply chain, retailers will reap the rewards of lowering costs related to inventory, transport, warehousing and packaging, while increasing customer satisfaction (Petty et al. 2012:463).

Worldwide, most new entrants to retailing unfortunately have no experience of retail selling and have to learn the trade through experience (Stokes \& Wilson 2010:387). In South Africa too, the dire need for more skilled entrepreneurs to run their small businesses efficiently and effectively is well known (Choto, Tengeh \& Iwu 2014:93-94; Lebusa 2013:76; Malebana \& Swanepoel 2015:109). Matabooe, Venter and Rootman (2016:2) advocate mentorship of older, established businesspeople towards new entrants. Retailers' need to learn from and emulate counterparts was observed by Kesavan and Kushwaha (2014:2118) who found that retailers, for example, benchmark their inventory performance against other organisations in the same industry or against competing retailers to guide their inventory decisions.

This article attempts to provide a guideline from literature and research reports that small business retailers can use in management decision-making on logistical supply chain drivers. The subsequent discussion commences with an overview of the orientation on which supply chain management strategies in small business are based upon. Thereafter a literature review is presented, which focusses on the state of logistics in South Africa as a developing country, the nature of logistics management decisions made in small businesses and the management of the three logistical supply chain drivers within the small business environment. The discussion on the main literature findings regarding the way in which management decisions related to the three logistical supply chain drivers differ (based on the supply chain strategy orientation) is structured in a Table. The final section consists of the conclusion, limitations posed by existing literature and future research opportunities.

\section{Supply chain management in small business}

Businesses often fail because of a lack of strategic fit between the competitive and supply chain strategies (Borella \& Padula 2010:44; Chopra \& Meindl 2016:33). A strategic fit can only be achieved when the goals of the supply chain strategy are aligned with the goals of the competitive strategy (Borella \& Padula 2010:47; Hoejmose, Brammer \& Millington 2012:589; Qrunfleh \& Tarafdar 2013:573; Soni \& Kodali 2011:71). Therefore, it is imperative that the supply chain design, resources and processes provide the necessary capabilities to support the desired competitive strategy.

When selecting a competitive strategy, small businesses will benefit from competing in narrow target markets, as they are often prevented from competing in large markets, mainly because of their limited resources (Box \& Miller 2011:58; Jooste et al. 2012:244; Leitner \& Güldenberg 2010:171; Parnell 2013:217; Teeratansirikool et al. 2013:170). Lazenby (2014:167) and Parnell (2013:217) explain that when small businesses compete in a narrow target market (defined either geographically, by products or services, or by customer type), they are more likely to succeed and maintain a competitive advantage than when competing in a broad target market.

Porter's generic competitive strategy framework is the dominant, universally accepted framework for competitive strategies within strategic management (Ehlers \& Lazenby 2010:179; Hsieh \& Chen 2011:14; Lazenby 2014:160; Salavou 2015:81). Although Porter's framework was developed in 1980 it is still deemed relevant within the modern business environment as it captures the essence on which more complex competitive strategies are based (Banker, Mashruwala \& Tripathy 2014:873). According to Porter (1985:11) a business' competitive advantage can be focussed, either on providing a product or service at the lowest possible cost (low cost), or on differentiating the product or service from rivals' offerings.

Differentiation as a source of competitive advantage is more suitable for innovative products with an uncertain customer demand, operating in an unstable and dynamic market environment and serving less price-sensitive customers (Salavou 2015:82). Small business managers using the focus differentiation competitive strategy should ensure that they are equipped to operate in an unstable and dynamic market environment by being flexible. They should implement appropriate functional strategies in order to adapt easily to changes in the market and fluctuating customer demand (Hsieh \& Chen 2011:14; Parnell 2013:217). In other words, 
these strategies must be managed to be responsive (Banker et al. 2014:874, 875; Hines 2013:40, 62-63).

The focus on low-cost competitive strategy is more suitable for functional products with certain customer demand, operating in stable and stationary markets and serving price-sensitive customers (Fawcett, Ellram \& Ogden 2007:228; Hsieh \& Chen 2011:14; Salavou 2015:82). Small businesses competing with a focus on low-cost competitive strategy should concentrate on lowering costs, for example by taking advantage of economies of scale (Banker et al. 2014:874, 875; Hines 2013:40, 62-63). After selecting an appropriate competitive strategy, the different functional strategies should be developed, which include the supply chain strategy (West, Ford \& Ibrahim 2015:34).

When selecting a supply chain strategy, management should consider the trade-off between the level of responsiveness and cost-efficiency at which they operate (Goldsby, Iyengar \& Rao 2014:143; Monczka et al. 2016:635; Simon et al. 2015:28; Storsjö, Martins \& Zanoni 2015:2); moreover, this strategy should also be aligned with the overall level of responsiveness and cost-efficiency of the entire supply chain (Chopra \& Meindl 2016:38). Although many factors (such as product characteristics; the level of demand and supply uncertainties placed on the supply chain; and customers' buying behaviour; the position of the supply chain member within the supply chain; order winners and order qualifiers) influence the selected supply chain strategy, the strategy will ultimately be orientated towards either responsiveness or cost-efficiency (Hines 2013:7). Table 1 depicts the characteristics of a supply chain strategy orientated towards responsiveness, directly followed by Table 2 that depicts the characteristics of a supply chain strategy orientated towards cost-efficiency.

Chopra and Meindl (2016:56) explain that obtaining the correct level of responsiveness and cost-efficiency - as stipulated by the specific supply chain strategy - depends on the unique interaction of the different elements within the supply chain. These elements are known as supply chain drivers. Three logistical supply chain drivers were identified by the aforementioned authors, namely facilities, inventory and transportation and three cross-functional supply chain drivers, namely information, pricing and sourcing. Although all six drivers should be managed effectively in order to obtain the correct level of responsiveness and cost-efficiency, this article will focus on the three logistical supply chain drivers as synchronisation agents in linking supply chain members with one another (Bowersox et al. 2013:4, 29). Before discussing the literature findings related to the management of logistical supply chain drivers in terms of obtaining the correct level of responsiveness and cost-efficiency, the logistics environment surrounding South African small businesses should be contextualised.

\section{Literature review State of logistics in South Africa as a developing country}

The World Bank rates the logistical performance of all countries every 2-3 years on a 5-point scale, where 1 indicates a low overall logistics performance level and 5 a high overall logistics performance level. Although South Africa's logistics performance fluctuated during 2007-2016 the country received its highest rating in 2016 - at 3.78, placing South Africa's logistics performance among upper middle income countries. An annual report that focusses on identifying logistical trends and opportunities for South African businesses (Barloworld Logistics Supply Chain Foresight 2016:3-4, 19, 25,28) has identified some logistical constraints that possibly contributed to the country's fluctuating logistics performance rating during that period. These constraints included the unstable economy, political uncertainty, high cost burdens (such as overheads) and skill shortages in both

TABLE 1: Characteristics of a supply chain strategy orientated towards responsiveness based on literature.

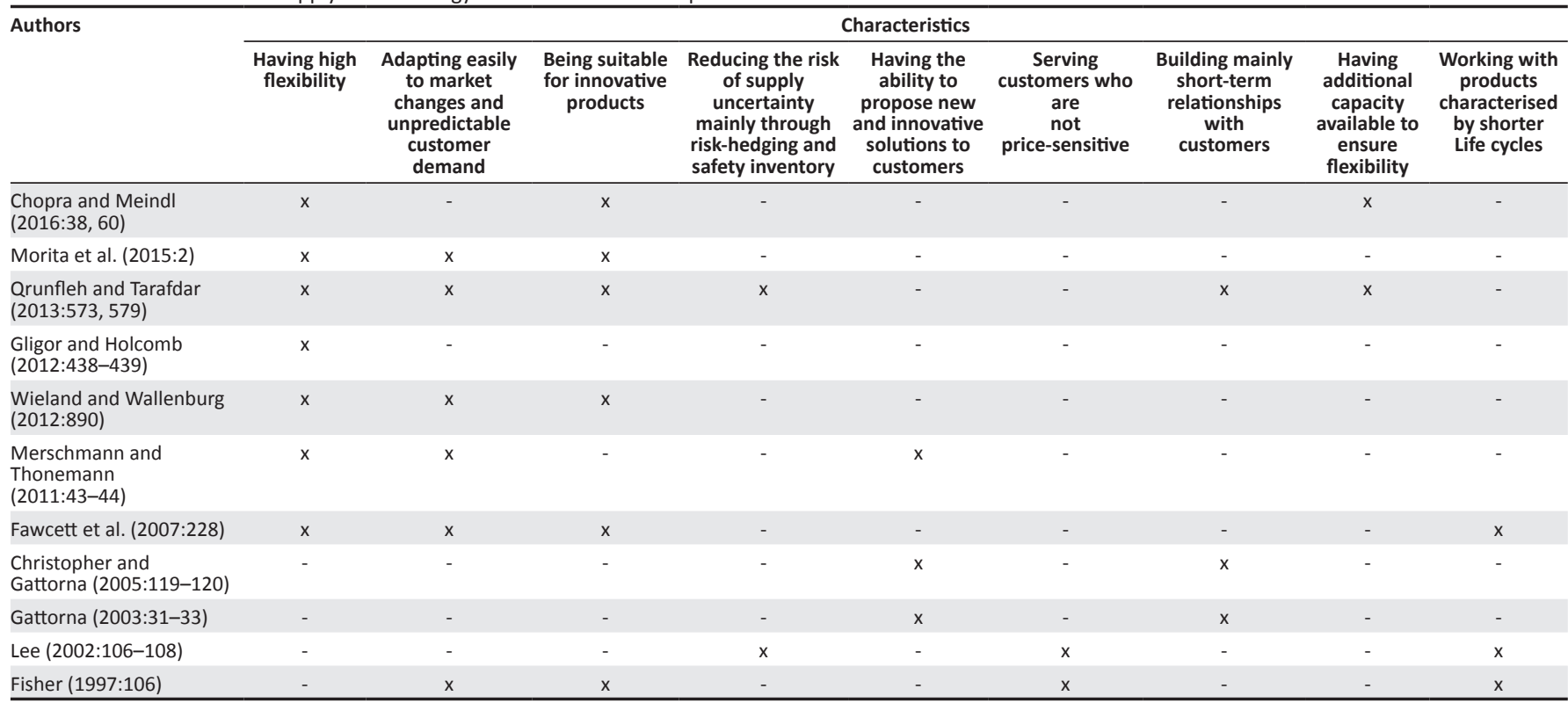

Note: Please see the full reference list of the article, Eicker, T. \& Cilliers, J.O., 2017, 'Equipping small business retailers to manage logistical supply chain drivers: A theoretical guideline', Journal of Transport and Supply Chain Management 11(0), a332. https://doi.org/10.4102/jtscm.v11i0.332, for more information. 
TABLE 2: Characteristics of a supply chain strategy orientated towards cost-efficiency based on literature. Authors

\begin{tabular}{|c|c|c|c|c|c|c|c|c|c|c|}
\hline & \multirow[b]{2}{*}{$\begin{array}{c}\text { Being } \\
\text { highly } \\
\text { cost- } \\
\text { conscious }\end{array}$} & \multirow{2}{*}{\multicolumn{2}{|c|}{$\begin{array}{cc}\begin{array}{c}\text { Focussing } \\
\text { on achieving } \\
\text { economies of } \\
\text { scale, synergy } \\
\text { and }\end{array} & \begin{array}{c}\text { Being suitable } \\
\text { when } \\
\text { customer } \\
\text { demand is } \\
\text { predictable }\end{array} \\
\begin{array}{c}\text { implementing } \\
\text { low-cost } \\
\text { processes }\end{array} & \\
\end{array}$}} & \multirow[b]{2}{*}{$\begin{array}{c}\text { Being } \\
\text { suitable for } \\
\text { functional } \\
\text { products }\end{array}$} & \multirow[b]{2}{*}{$\begin{array}{l}\text { Reducing the } \\
\text { risk of } \\
\text { supply } \\
\text { uncertainty } \\
\text { mainly through } \\
\text { pooling or } \\
\text { sharing of } \\
\text { resources }\end{array}$} & \multirow[b]{2}{*}{$\begin{array}{c}\text { Serving } \\
\text { price- } \\
\text { sensitive } \\
\text { customers }\end{array}$} & \multirow[b]{2}{*}{$\begin{array}{l}\text { Building } \\
\text { long-term } \\
\text { relationships } \\
\text { with customers } \\
\text { mainly to } \\
\text { share } \\
\text { knowledge }\end{array}$} & \multirow[b]{2}{*}{$\begin{array}{l}\text { Focussing } \\
\text { on } \\
\text { cost- } \\
\text { competition }\end{array}$} & \multirow[b]{2}{*}{$\begin{array}{c}\text { Using } \\
\text { demand } \\
\text { forecasts }\end{array}$} & \multirow[b]{2}{*}{$\begin{array}{l}\text { Working } \\
\text { with } \\
\text { products } \\
\text { characterised } \\
\text { by longer } \\
\text { life cycles }\end{array}$} \\
\hline & & & & & & & & & & \\
\hline Monczka et al. (2016:636) & $\mathrm{x}$ & $x$ & - & - & - & $x$ & - & - & - & - \\
\hline $\begin{array}{l}\text { Wisner, Tan and Leong } \\
(2016: 112)\end{array}$ & - & - & $x$ & $\mathrm{x}$ & - & - & - & - & - & $\mathrm{x}$ \\
\hline Liu et al. (2014:112-113) & - & - & - & - & $x$ & - & - & - & - & - \\
\hline $\begin{array}{l}\text { Qrunfleh and Tarafdar } \\
(2013: 573)\end{array}$ & - & $x$ & - & - & - & $x$ & - & $x$ & $\mathrm{x}$ & - \\
\hline Gattorna (2010:169) & - & - & - & - & - & - & $x$ & - & - & - \\
\hline Fawcett et al. (2007:228) & - & $x$ & - & - & - & $x$ & - & - & - & - \\
\hline Hong and Jeong (2006:296) & - & - & $\mathrm{x}$ & $\mathrm{x}$ & - & - & - & $x$ & - & $\mathrm{x}$ \\
\hline $\begin{array}{l}\text { Christopher and Gattorna } \\
(2005: 119-120)\end{array}$ & - & $x$ & - & - & - & - & $x$ & - & - & - \\
\hline Lee (2002:106-107) & - & - & $x$ & $x$ & - & - & $x$ & $x$ & - & $x$ \\
\hline Fisher (1997:106) & $x$ & - & $x$ & $x$ & - & - & - & - & - & $\mathrm{x}$ \\
\hline
\end{tabular}

Note: Please see the full reference list of the article, Eicker, T. \& Cilliers, J.O., 2017, 'Equipping small business retailers to manage logistical supply chain drivers: A theoretical guideline', Journal of Transport and Supply Chain Management 11(0), a332. https://doi.org/10.4102/jtscm.v11i0.332, for more information.

upper and lower management. These constraints are in line with those faced by other developing countries, such as China and Malaysia (Li \& Fung Research Centre 2008; Zuraimi, Yaacob \& Ibrahim 2013:326).

According to the Council for Scientific and Industrial Research's (CSIR) 10th Annual State of Logistics Survey for South Africa (2014:28), the performance of South Africa's logistics industry is dependent on the country's transport infrastructure, logistics service provision, cross-border trade facilitation and telecommunication systems. The CSIR survey (2014:1-7) further explains that South Africa's economy is classified as a high transport-intensive economy, where products have to be transported frequently to fulfil demand (Havenga \& Simpson 2014:35) because of the vast imbalance between the demand and supply of products. The Logistics Barometer of South Africa is a platform created by the Stellenbosch University's Department of Logistics to report on the national logistics costs, the different cost drivers and the latest logistics trends in the country. Figure 1 illustrates the different components of South Africa's logistics costs as reported by The Logistics Barometer of South Africa for 2013, 2014 (estimated) and 2015 (forecasted). ${ }^{1}$

Aligned with the CSIR's survey The Logistics Barometer also classified South Africa as a high transport-intensive economy because approximately $60 \%$ of all logistics costs for this period were classified as transportation costs. Warehousing costs ranged between $13 \%$ and $14 \%$ of total logistics costs and inventory carrying costs between $13 \%$ and $15 \%$ of total logistics cost during the period 2013-2015. South Africa's estimated cost of logistics as a percentage of gross national income for 2014 and 2015 was $11.4 \%$ and $11.7 \%$ respectively, which was again in line with other developing countries (Stellenbosch University 2015:4, 7).

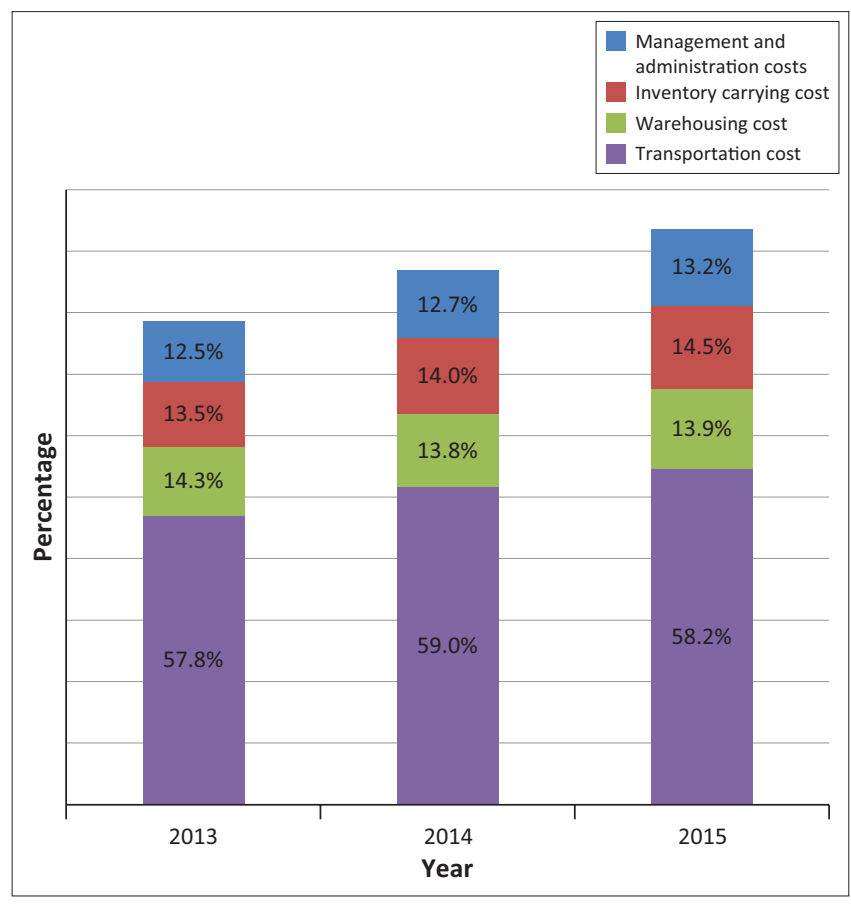

Source: Stellenbosch University, 2015, Logistics barometer South Africa, p. 7, viewed 21 September 2015, from http://www.sun.ac.za/english/faculty/economy/logistics/ Documents/Logistics\%20Barometer/Logistics\%20Barometer\%202015.pdf

FIGURE 1: Cost components of South Africa's logistics costs for the period 2013 2015 in percentages.

\section{Logistics management in small businesses}

According to Soinio, Tanskanen and Finne (2012:33) small businesses are normally characterised as not having the ability to manage their logistics activity. An effective logistics network can serve as a differentiating factor to distinguish a business from its competitors (Nichols 2010; Wisner et al. 2016:301). The performance of a small business is directly influenced by logistics and can be enhanced by reducing overall logistics costs, for example by reducing inventories and managing transportation efficiently (Orfanos, Mylonakis \& Evripiotis 2010:21, 26). Although small businesses are more simply 
structured in terms of the number of employees, annual turnover, capital assets and the managerial involvement of its owners than larger businesses (Erasmus, Strydom \& Rudansky-Kloppers 2013:52; Töyli et al. 2008:61), their logistics challenges remain the same. The essential components (drivers) of facilities, inventory and transportation, as well as the logistics linkages (identified by Monczka et al. 2016:659 as inbound logistics, intra-organisational movements, outbound logistics and reverse logistics) are present in both large and small businesses (Zowada 2013:116). Therefore, the logistics management decisions made by small business owners will in essence resemble the management decisions made in larger businesses, as confirmed in the literature review presented below.

\section{Logistical supply chain drivers}

Although the three logistical supply chain drivers cannot be managed in isolation (Chopra \& Meindl 2016:57), each driver is presented separately in the subsequent sections for discussion purposes. The discussion will consider the role of each supply chain driver within a retail supply chain; the different management decisions related to each supply chain driver; and the different decisions small business management need to make regarding the business' orientation towards responsiveness and cost-efficiency.

\section{Facilities as a logistical supply chain driver}

Facilities provide supply chain services that include the storage of inventory, customer order fulfilment and assembling of different parts of a product. If these services are managed and designed effectively, it can result in improved customer service through increased responsiveness (Wisner et al. 2016:318). When facility decisions are aligned with the orientation of the selected supply chain strategy, businesses tend to be more successful (Chopra \& Meindl 2016:59). Businesses can use facilities as a source of a competitive advantage, based on reducing either cost or lead times (Graungaard Pedersen, Zachariassen \& Stentoft Arlbjørn 2012:354). Designing a facility network entails decisions related to the function, location and capacity of the facility, which will impact supply chain performance in terms of the level of responsiveness and costefficiency (Horn et al. 2014:15). The different management decisions related to facilities are discussed below.

Function of the facility: Facilities can be classified, for example, as production, storage, the premises from which a retailer operates or as a service facility according to its function. When retailing physical goods, the premises from which retailers operate, represents their facilities, service facilities constitute those places where services are rendered to customers, often with the aid of inventory items (Bowersox et al. 2013:37; Lawrence, Sivakumar \& Arivarignan 2013:4771). Retail premises represent a convenient, permanent place of contact between buyers and sellers - which retailers should use to their advantage (Stokes \& Wilson 2010:387).

When designing or selecting the premises for retail outlets, managers should consider their target market. Factors, such as product variety and level of shopping convenience, will influence the size and layout of the retail premises (Kotler et al. 2013:435). For example, a small retailer who strives to provide customers with a fast shopping experience would focus on obtaining a larger retail premises designed for fast and convenient shopping. Service retailers must aim to balance the optimal rate at which a service is provided and the cost of providing the service (Berman \& Sapna 2001:429). An increase in the rate of providing the service will increase cost, such as overheads and storing costs (if applicable) as the retailer has to ensure that inventory and staff are available, whereas a decrease in the rate of providing a service will lead to a decrease in costs, as less inventory can be kept (if applicable) and less staff employed. Managing service facilities to reduce customers' waiting periods (lead times) will increase not only the retailer's level of responsiveness, but also its profit, as more customers can be assisted (Berman \& Sapna 2001:429).

Retailers also require a facility to store additional inventory. Inventory can be stored either at the premises from which the business is operated or at a facility located elsewhere. Smaller retailers are known to use a storage facility (or room) at their retail premises to store inventory (Fernie \& Sparks 2014:4). A storage facility can be used to hold several types of inventory, for example safety or seasonal inventory in preparation for fluctuating customer demand (Baker \& Canessa 2009:425; Richards 2014:9). The amount of inventory that the retailer decides to store directly impacts the size of the storage facility, as well as the level of responsiveness and costefficiency at which the retailer operates (Chopra \& Meindl 2016:60). A retailer would require an additional facility (or room) to store excess inventory in order to meet customers' needs immediately at the expense of increased facility costs. On the other hand, a retailer who are more focussed on costefficiency would generally not hold excess inventory eliminating the need for an additional facility (or room) and keeping facility cost low, at the expense of not meeting customers' needs immediately (Kamath \& Roy 2007:336).

Location of the facility: Retail businesses with brick-andmortar sites generally focus on the revenue-generating potential of locations, as opposed to the cost focus of manufacturers and wholesalers. When selecting a location, retailers have to consider the drawing power of the location, the match between the target market and the demographics of the customer-drawing area and the competitive environment (Mariotti \& Glackin 2012:495). Hatten (2012:308) further stresses the importance of retail compatibility when retailers select a location. Shoppers tend to be drawn to clusters of related businesses, which synergistically serve the market (Hatten 2012:308). Retailers should realise that shopping malls and centres could potentially draw more foot traffic. Although costly, the benefits of establishing a business in malls and shopping centres to sell complementary products or compete directly with similar offerings could outweigh the benefits associated with a more cost-efficient single free-standing location (Mariotti \& Glackin 2012:495; Scarborough 2011:477). The decision of service providers on 
location differs somewhat in that service businesses would need access to their customers and can generally survive in lower-rent properties (Scarborough 2011:476). If professional services are offered managers would require attractive office space that is easily accessible because the image they portray is crucial (Allen 2012:310).

Another key factor for retail businesses is the proximity of outlets to the customers they serve. Thus managers should decide to either use a centralised or decentralised facility system. When using a centralised facility system, a business will have fewer facilities than with a decentralised facility system. The advantages of a centralised facility system lie in lower facility costs (for example administration costs) and increased efficiency of the facility through economies of scale (decreasing the facility cost per unit) (Graungaard Pedersen et al. 2012:353). The disadvantages of a centralised facility system are increased transportation costs and delivery times because of the increased distances that inventory items travel between suppliers, customers and the facility. Therefore, a centralised facility system can increase cost-efficiency (if the cost advantage gained from economies of scale outweighs the increase in transportation costs) at the expense of responsiveness (because of longer distances travelled). Gaining the advantages of economies of scale (by purchasing in large quantities), when using a centralised facility system, may prove to be more difficult for smaller businesses with their limited resources (Graungaard Pedersen et al. 2012:366).

Alternatively, when using a decentralised facility system, a business will have more facilities available. The advantages of using a decentralised facility system lie in the shorter distances and delivery times of inventory items between the suppliers, customers and facilities (Schmitt et al. 2015:202). Holding inventory closer to customers allows a retailer to reduce transportation costs and meet customers' needs faster (Richards 2014:20).

Capacity of the facility: The capacity of a facility refers to a number of issues, such as the maximum average rate at which inventory can flow through the system; the rate at which a service can be rendered; or the available storage space at a facility (Bowersox et al. 2013:103; Wisner et al. 2016:527). The available capacity of a facility influences business performance in terms of responsiveness and costefficiency (Chopra \& Meindl 2016:60). Having excess capacity will increase costs, but will enable the business to respond swiftly to changes in customer demand (Kamath \& Roy 2007:336). Excess storage capacity will allow a business to store additional inventory and have the items on hand whenever customer demand arises. Additional capacity for service retailers can, for example, lie in having extra time available to perform additional services. Although excess capacity can increase the level of responsiveness, costefficiency will decrease, as idle capacity does not generate revenue and also increases facility costs (Hugos 2006:10-11). On the other hand, by not having excess capacity available, the level of cost-efficiency increases (because of a decrease in facility costs), at the expense of the level of responsiveness, as any change in customer demand cannot be met timeously.

Small retailers must decide whether they prefer to make provision for fluctuations in customer demand by having additional capacity (thus increased responsiveness at higher cost), or whether they would rather wait until a customer's demand is known. This will allow retailers to purchase the appropriate level of inventory from suppliers, and so eliminate the need for excess capacity (thus increasing costefficiency at the expense of responsiveness) (Chopra \& Meindl 2016:60-61).

\section{Inventory as a logistical supply chain driver}

Inventory is kept in a supply chain to address the imbalance between the supply and demand of products (Chopra \& Meindl 2016:61) and should be managed effectively as one of the business' most expensive assets (Monczka et al. 2016:621622; Wisner et al. 2016:209). The right amount of inventory should be purchased to support the business' day-to-day activities because ineffective inventory management can lead to excess inventory and a waste of resources (Wisner et al. 2016:209). Poor and ineffective inventory management directly impacts the growth of small business negatively (Mbonyane \& Ladzani 2011:553). Alhabeeb (2015:244) states that inventory is used to achieve the objectives of operational flexibility, avoiding product stock-outs, saving on purchasing cost through quantity discounts and regulating product supply while considering the cost implications of these objectives. Businesses incur a number of different costs when building and maintaining inventory levels, such as the cost of ordering and purchasing inventory, carrying and storing costs, as well as the cost of loss in sales because of stock-outs.

The role of changes in the economic environment cannot be ignored during inventory decision-making. Kesavan and Kushawa's (2014:2120) main finding of research conducted among public retailers in the USA was that stock-outs and the inventory-holding costs facing retailers have a significant, explanatory power over the observed differences in inventory investment behaviour across retailers during economically turbulent times. Higher inventory costs would imply smaller profits and eventually lower inventory levels. The challenge lies in finding the right balance between the amount of inventory that businesses should carry to satisfy unpredictable customer demand and the cost of carrying such inventory (Alhabeeb 2015:242; Ehrenthal, Honhon \& Van Woensel 2014:527; Pienaar \& Vogt 2012:218). Inventory can be classified as either cycle, safety or seasonal inventory, depending on the purpose of the inventory. Managers need to consider both the amount of each type of inventory to hold, as well as the cost implication of holding the inventory as this has a direct influence on the level of responsiveness and cost-efficiency of the business (Chopra \& Meindl 2016:62).

Cycle inventory: Cycle inventory is the average amount of inventory that is purchased or produced in order to satisfy customer demand within a specific cycle (weekly or monthly 
or annually) (Horn et al. 2014:80). Within the retail sector, cycle inventory will include products that retailers sell to customers, products that a service provider uses to render the service to customers (Berman \& Sapna 2001:430) and products that retailers use to produce other products (for example a bakery). When ordering cycle inventory, managers must first consider the amount and frequency of inventory that is required (Islam et al. 2013:3-4). Businesses that purchase cycle inventory in large batches do so to take advantage of economies of scale; as this will lead to a decrease in the costs of transportation, ordering and purchasing. While purchasing cycle inventory in large batches decreases costs, managers should be aware of the cost increase in carrying a large amount of inventory, for example increased facility costs. On the other hand, by ordering cycle inventory in smaller batches more often, retailers will be able to meet customer demand more often as inventory is readily available at the cost of increased transportation, ordering and purchasing costs (Chopra \& Meindl 2016:62, 280). Owner or managers can follow inventory management practices by investing in inventory control systems and using basic quantitative techniques to optimise their inventory levels, such as computing inventory turnover ratios, determining the economic ordering quantity, calculating and setting reorder points for maximum and minimum inventory levels, doing regular inventory counts and setting inventory budgets (Abanis et al. 2013:31, 36, 40).

Safety inventory: Any additional inventory held above cycle inventory is classified as safety inventory. The purpose of safety inventory is to prevent a loss of sales because of stockouts (Coyle et al. 2013:324). Therefore, safety inventory buffers a business against unpredictable customer demand (Baker \& Canessa 2009:425; Bowersox et al. 2013:48). Managers should carefully determine the amount of safety inventory items to hold, because if a surplus is held, a markdown may be required in order for these items to be sold. Not only will income be lost (because of the mark-downs), but the carrying cost will decrease cost-efficiency (Graungaard Pedersen et al. 2012:354). On the other hand, insufficient safety inventory may result in decreased responsiveness, and a consequent loss in sales (Baily et al. 2008:164). The managers of small retail businesses should determine the level of safety inventory depending on their orientation towards cost-efficiency or responsiveness. Johnson and Ruankaew (2017:12) propose that the efficiency in inventory control in small businesses requires the adoption of inventory control techniques, such as economic reorder points, classification of inventory, forecasting and safety inventory levels. As in the case of cycle inventory, the ability to calculate the reorder point would allow owners or managers to determine the demand during lead time and the safety inventory needed during stock-outs or before replenishment takes place (Badenhorst-Weiss, Van Biljon \& Ambe 2017:141). Automation in inventory management can add value in small businesses by triggering reorder points to reduce stock-outs or by enabling forecasting for better purchases or by calculating the economic ordering quantities for replenishment (Johnson \& Ruankaew 2017:13).
Seasonal inventory: Inventory that is accumulated to counter predictable seasonal customer demand is called seasonal inventory. Retailers will purchase additional inventory in times when customer demand is low, in preparation for times when demand is high (Chopra \& Meindl 2016:63; Ehrenthal et al. 2014:527). The decision to purchase seasonal inventory depends mainly on whether the retailer views the increase in carrying cost worth having the products available when customer demand is higher. Therefore, purchasing seasonal inventory will increase the retailer's level of responsiveness, at the expense of cost-efficiency (Chopra \& Meindl 2016:63).

\section{Transportation as a logistical supply chain driver}

Transportation is an important part of logistics and a key driver within supply chain management (Monczka et al. 2016:659). Transportation does not only refer to moving inventory, but also to the delivery of a service to a customer. Transportation reduces the business' financial resources through costs for, among others, labour, fuel, vehicles and vehicle maintenance (Bowersox et al. 2013:187). Transportation should be managed effectively and costefficiently because it generally forms one of the largest logistics expenses for any business (Bowersox et al. 2013:187). Effective transportation management refers to the extent to which transportation contributes to meeting customer needs, whereas cost-efficient transportation management measures how economical transportation can be used to meet customer needs. Holter et al. (2008:22) identify two reasons for the importance of transportation management, particularly in small businesses. First, transportation is a process that is repeated numerous times throughout the supply chain, and secondly, transportation is one of the most costly logistical activities for many small businesses, as already mentioned. Through the effective and cost-efficient management of transportation, customers' expectations can easily be met (Bowersox et al. 2013:187). For small retailers, transportation in the supply chain will entail collecting or receiving inventory from a supplier, and delivering inventory to customers (if a delivery service is offered). The different routes and modes, by which inventory is transported to different locations, are referred to as the transportation network. A well-designed transportation network will assist a supply chain to achieve the desired level of responsiveness at the lowest possible cost (Chopra \& Meindl 2016:64).

Routes of transportation: Chopra and Meindl (2016:64-65) state that when designing a transportation network, managers should consider two aspects; firstly, whether the inventory will be transported directly from the supplier to the customer and secondly, whether the inventory will pass through an intermediate site, such as a cross-docking distribution centre. Direct shipment of inventory indicates that inventory does not go through an intermediate storage site, but is directly transported from a supplier to a customer. This means that the coordination between the different supply chain members is relatively easy in many ways, for example, the scheduling of delivery times. According to these authors direct delivery will minimise the time that inventory spends in transit resulting in 
increased responsiveness. On the other hand, when inventory is transported through an intermediate site the items are usually sent to a cross-docking distribution centre. When a cross-docking distribution centre is used, a supplier will send a truck containing several customers' inventories to the centre to be combined with inventories from other suppliers. By coordinating and sharing transportation, the inbound costs can be lowered. An outbound truck will combine the inventories from several suppliers destined for one customer (Chopra \& Meindl 2016:423; Yu \& Egbelu 2013:168). In a storage facility, inventory from a supplier is received and stored until a customer needs the inventory. Inbound transportation costs decrease because suppliers can benefit from economies of scale by sending large shipments of inventory to the storage facility. Normally the outbound transportation costs are low, as the storage facility centre is located close to customers when using a decentralised facility system (Chopra \& Meindl 2016:423).

Road transportation: Small businesses primarily use road transportation and select small delivery trucks and motor vehicles to move inventory from its point of origin to its final destination in the supply chain (Goldsby et al. 2014:24). Road transportation is viewed as the most popular mode of transportation based on its speed and reliability (Goldsby et al. 2014:17; Monczka et al. 2016:671). Furthermore, the available highway networks enable vehicles to reach nearly every shipping and receiving location (Coyle et al. 2013:405-406). The ability of road transportation to deliver door-to-door also makes it the most flexible mode of transportation. However, this flexibility comes at a cost because transportation by road is relatively more expensive (Monczka et al. 2016:669). Although more expensive, the advantage of easy access to the final location normally outweighs the additional costs, according to Chopra and Meindl (2016:416). In essence, road transportation will increase a retailer's level of responsiveness, but at the same time will decrease the level of cost-efficiency (Hugo \& Badenhorst-Weiss 2011:179-180). It should however be noted that South African retailers are restricted by the available infrastructure to mainly use road transportation. Therefore, despite enjoying the benefits related to responsiveness, they have to manage transport costing efficiently. Although De Villiers, Nieman and Niemann (2017:170) summarise the components associated with road transport costing as fixed (or standing) costs, variable (or running) costs and overhead costs small business retail owners or managers would typically consider fixed and variable costs. For example, aspects such as vehicle depreciation and vehicle insurance are included as part of fixed costs if they own the vehicle. Variable costs would entail fuel and lubricant expenses when owning a vehicle and carrier rates when outsourcing transportation. When considering costs, small business owners should base their decisions on two fundamental principles impacting on transport efficiency, namely economy of scale and economy of distance (Bowersox et al. 2013:203-204). A small business owner or manager can achieve economy of scale in transportation by transporting full loads or by collaborating with other small businesses to have a full load because the economy of scale principle holds that transportation cost per unit will decrease as the size of the shipment (or load) increases. Similarly, economy of distance refers to decreased transportation cost per ton $/ \mathrm{kg}$ as the distance (in $\mathrm{km}$ ) increases. According to this principle, fixed transportation costs can be spread over more kilometres travelled which implies lower per kilometre charges. Thus, if a small business owner could source products at a good price from a supplier located further away, fixed transportation costs can be lower. To summarise, based on the principles of economy of scale and economy of distance, small business owners can be cost-efficient by maximising the load size and the distance transported within the boundaries of meeting customer service expectations and considering the variable costs incurred.

\section{Discussion of findings}

Table 3 summarises literature findings on general facility, inventory and transportation management decisions based on a small retail business' (including service retailers') orientation towards either responsiveness or cost-efficiency, as aligned with its supply chain strategy.

The management decisions regarding the logistical supply chain drivers presented in Table 3 will contribute to achieving either responsiveness or cost-efficiency in different ways. Small business retailers who base their supply chain strategy on responsiveness would carry excess inventory (stored either at the premises or a storage facility) in order to satisfy customers' needs conveniently and immediately with available products. Similarly, a responsive service retailer will organise (arrange) the facility to provide customers with a seamless service experience because of shorter waiting times and the availability of sufficient staff and goods to render the service. In terms of location, responsive retailers will be driven by being close to customers to satisfy their need for convenience and shorten their waiting times. Therefore, they would find a location close to customers and, if necessary, open another outlet that is geographically closer to customers. They would also show a preference for being situated between clusters of related businesses (often in malls and shopping centres) to provide complementary products and contribute to a convenient and time-saving shopping experience. In their effort to be able to provide sufficient products or services, responsive small business retailers will ensure that extra capacity (or space) is available for storing items for immediate satisfaction. In terms of inventory management responsive small retailers order smaller batches regularly (even at higher cost) and buy additional inventory (safety inventory) in order to have inventory available as demand changes. Such additional inventory would require additional storage space. When making transportation decisions, responsive small retailers will, if the occasion demands, resort to direct delivery from suppliers (and to customers) to speedily provide the products and services required. The availability of road transportation as the main option available to South African small retailers favours the responsive small retailer because of the speed, flexibility and reliability associated with this mode of transportation. However, meeting customer expectations should outweigh the costs incurred. 
TABLE 3: Logistical supply chain drivers' management decisions.

\begin{tabular}{|c|c|c|c|c|}
\hline $\begin{array}{l}\text { Supply chain } \\
\text { driver }\end{array}$ & $\begin{array}{l}\text { Components of decisions } \\
\text { related to facilities }\end{array}$ & $\begin{array}{l}\text { Management decision when focussed on } \\
\text { responsiveness }\end{array}$ & $\begin{array}{l}\text { Management decision when focussed on } \\
\text { cost-efficiency }\end{array}$ & Relevant authors \\
\hline \multirow[t]{4}{*}{ Facilities } & $\begin{array}{l}\text { Classification as storage, } \\
\text { retail or service facility }\end{array}$ & $\begin{array}{l}\text { Facility characteristics: } \\
\text { - Excess inventory (safety or seasonal) is purchased } \\
\text { and stored, either in-store or at a storage facility } \\
\text { situated away from the retailer. } \\
\text { - Retail facility (premises) is designed to increase the } \\
\text { customer's level of shopping convenience. Ample } \\
\text { storage space is available at the retail premises to } \\
\text { store additional inventory. } \\
\text { - Service facility is managed to reduce the time that } \\
\text { customers wait to receive the specific service (lead } \\
\text { time). Facility is flexible- by holding sufficient } \\
\text { inventory and staff to perform the service. }\end{array}$ & $\begin{array}{l}\text { Facility characteristics: } \\
\text { - Excess inventory (safety or seasonal) is not } \\
\text { purchased, and therefore there is no } \\
\text { need for a storage facility. } \\
\text { - A smaller retail facility (premises) is selected } \\
\text { as limited or no excess inventory is held. } \\
\text { - Service facility is managed to focus on } \\
\text { reducing costs by not holding excess inventory } \\
\text { and employing only the necessary number } \\
\text { of staff members. }\end{array}$ & $\begin{array}{l}\text { - Richards (2014:9) } \\
\text { - Bowersox et al. } \\
\text { (2013:37) } \\
\text { - Kotler et al. (2013:435) } \\
\text { - Lawrence et al. } \\
\text { (2013:4771) } \\
\text { - Berman and Sapna } \\
\text { (2001:429, 430) }\end{array}$ \\
\hline & \multirow[t]{2}{*}{ Location } & $\begin{array}{l}\text { Number of stores: } \\
\text { - An additional shop is rather opened in order to be } \\
\text { located close to more customers, than expanding } \\
\text { current facility (decentralised system). }\end{array}$ & $\begin{array}{l}\text { Number of stores: } \\
\text { - Having only one facility from where the } \\
\text { business is operated (centralised system). }\end{array}$ & \multirow{2}{*}{$\begin{array}{l}\text { - Chopra and Meindl } \\
\text { (2016:59) } \\
\text { - Wisner et al. (2016:321) } \\
\text { - Schmitt et al. (2015:202 } \\
\text { - Richards (2014:20) } \\
\text { - Coyle et al. (2013:474) } \\
\text { - Allen (2012:310) } \\
\text { - Graungaard Pedersen et } \\
\text { - } \text { al. (2012:353) } \\
\text { - Mariotti and Glackin } \\
\text { (2012:495) } \\
\text { - Scarborough (2011:477) }\end{array}$} \\
\hline & & $\begin{array}{l}\text { Retail compatibility: } \\
\text { - Situated between clusters of related businesses } \\
\text { generally within costly malls or shopping centres. }\end{array}$ & $\begin{array}{l}\text { Retail compatibility: } \\
\text { - Situated at a lower cost, free-standing location. }\end{array}$ & \\
\hline & $\begin{array}{l}\text { Capacity or available } \\
\text { space }\end{array}$ & $\begin{array}{l}\text { Excess capacity: } \\
\text { - Excess capacity is available to render a service } \\
\text { or to store inventory. }\end{array}$ & $\begin{array}{l}\text { Excess capacity: } \\
\text { - Fixed capacity is available to render } \\
\text { services and store inventory. }\end{array}$ & $\begin{array}{l}\text { - Wisner et al. (2016:527) } \\
\text { - Fernie and Sparks } \\
\text { (2014:4) } \\
\text { - Bowersox et al. } \\
\text { (2013:103) } \\
\text { - Kamath and Roy } \\
\text { (2007:336) } \\
\text { - Hugos (2006:10-11) }\end{array}$ \\
\hline \multirow[t]{3}{*}{ Inventory } & Cycle inventory & $\begin{array}{l}\text { Order frequency of cycle inventory: } \\
\text { - Order frequently and in smaller batches for } \\
\text { immediate satisfaction of customer demand, } \\
\text { thereby forgoing the possibility of saving costs (such } \\
\text { as ordering, carrying and transportation costs). }\end{array}$ & $\begin{array}{l}\text { Order frequency of cycle inventory: } \\
\text { - Order less frequently to minimise costs } \\
\text { (such as ordering, carrying and transportation } \\
\text { costs) and in large batches to benefit from } \\
\text { economies of scale. }\end{array}$ & $\begin{array}{l}\text { - Chopra and Meindl } \\
\text { (2016:62, 280) } \\
\text { - Islam et al. (2013:3-4) } \\
\text { - Graungaard Pedersen et } \\
\text { al. (2012:352-353) }\end{array}$ \\
\hline & $\begin{array}{l}\text { Safety (or excess) } \\
\text { inventory }\end{array}$ & $\begin{array}{l}\text { Quantity of safety inventory kept: } \\
\text { - Hold a large amount of safety inventory items to } \\
\text { ensure immediate satisfaction of customer demand. }\end{array}$ & $\begin{array}{l}\text { Quantity of safety inventory kept: } \\
\text { - Hold a small amount of inventory items } \\
\text { to save on costs (such as carrying costs } \\
\text { and loss of income because of mark-downs). }\end{array}$ & $\begin{array}{l}\text { - Bowersox et al. } \\
\text { (2013:48) } \\
\text { - Coyle et al. (2013:324) } \\
\text { - Baker and Canessa } \\
\text { (2009:425) } \\
\text { - Baily et al. (2008:164) }\end{array}$ \\
\hline & Seasonal inventory & $\begin{array}{l}\text { Provision for seasonal demand: } \\
\text { - Purchase additional products in off-peak periods } \\
\text { to make provision for increased demand in } \\
\text { peak periods. }\end{array}$ & $\begin{array}{l}\text { Provision for seasonal demand: } \\
\text { - Do not make provision in off-peak periods for } \\
\text { increased demand in peak periods; instead } \\
\text { save on costs (such as carrying costs) during } \\
\text { off-peak periods. }\end{array}$ & $\begin{array}{l}\text { - Chopra and Meindl } \\
\text { (2016:63) } \\
\text { - Wisner et al. (2016:211) } \\
\text { - Ehrenthal et al. } \\
\text { (2014:527) }\end{array}$ \\
\hline \multirow[t]{2}{*}{ Transportation } & Routes & $\begin{array}{l}\text { Delivery of inventory: } \\
\text { - Use direct delivery of inventory from and to } \\
\text { first-tier suppliers and customers in order to } \\
\text { minimise transit time and to } \\
\text { increase responsiveness. }\end{array}$ & $\begin{array}{l}\text { Delivery of inventory: } \\
\text { - Order large quantities of inventory to qualify for } \\
\text { free delivery from suppliers. Larger retailers may } \\
\text { have inventory delivered to an intermediate site } \\
\text { to lower inbound transportation costs. }\end{array}$ & $\begin{array}{l}\text { - Chopra and Meindl } \\
\text { (2016:64-65) } \\
\text { - Yu and Egbelu } \\
\text { (2013:168) }\end{array}$ \\
\hline & Transportation mode & $\begin{array}{l}\text { Road transportation: } \\
\text { - Fast, flexible transportation mode making access } \\
\text { to end locations easy. Lead times are reduced } \\
\text { when using road transportation. }\end{array}$ & $\begin{array}{l}\text { Road transportation: } \\
\text { - Maximum load size and distance transported } \\
\text { to take advantage of economy of scale } \\
\text { and economy of distance. }\end{array}$ & $\begin{array}{l}\text { - De Villiers et al. } \\
\text { (2017:170) } \\
\text { - Monczka et al. } \\
\text { (2016:671) } \\
\text { - Goldsby et al. (2014:17) } \\
\text { - Bowersox et al. } \\
\text { (2013:203-204) } \\
\text { - Hugo and Badenhorst- } \\
\text { Weiss (2011:179-180) }\end{array}$ \\
\hline
\end{tabular}

Note: Please see the full reference list of the article, Eicker, T. \& Cilliers, J.O., 2017, 'Equipping small business retailers to manage logistical supply chain drivers: A theoretical guideline', Journal of Transport and Supply Chain Management 11(0), a332. https://doi.org/10.4102/jtscm.v11i0.332, for more information.

The small retailer driven by cost-efficiency shows no need for a bigger store (or service facility) or a storage facility because of their decision not to keep excess inventory items (or to appoint additional staff for rendering the service). Cost reduction also explains their decision to operate from a single, free-standing facility in a less costly location. A costefficient orientation might result in the facilities being situated further away if retailers can benefit from reduced transportation costs (and other costs) and economy of scale associated with a centralised facility. Being restricted in terms of capacity eliminates the cost of carrying additional inventory or rendering additional services. Cost-efficient retailers benefit from achieving economy of scale by ordering large batches of cycle inventory less frequently. They are however more cautious to carry safety inventory at extra cost and keep only a small number of items for which larger costly space need not be rented. They would also rather save on inventory costs during off-peak seasons (and not make provision for increased demand in peak seasons) by not stocking up on such items. In terms of transportation savings, cost-efficient small retailers benefit from free deliveries associated with large orders. As already mentioned 
South African small retailers are bound to use road transportation and therefore the cost-driven small retailer will have to achieve economy of scale and economy of distance, even if that entails collaboration with other retailers. However, such savings should not compromise satisfying customer needs and the variable costs incurred.

\section{Future research opportunities}

Empirical studies can be conducted to determine the application of these guidelines in different retail settings. Because this literature study focussed only on the management of the three logistical supply chain drivers by small retailers, future research could focus on determining (by means of a literature study and empirically) how retailers should manage the three cross-functional supply chain drivers, namely information, sourcing and pricing.

\section{Limitations of the study}

The authors found that the literature related to the management of the three logistical supply chain drivers were mainly conceptualised and presented for small businesses operating in a developed economy. Therefore, some of the suggestions related to the management of the logistical supply chain drivers to either increase the retailers' level of responsiveness of cost-efficiency might not be feasible for South African small businesses, unless empirically established. Furthermore, the literature findings from which the guidelines were deduced did not include a discussion on all three logistical drivers, which neglected the cohesion and interaction between the drivers. Finally, the authors did not structure the literature to specifically distinguish between decisions promoting either responsiveness or cost-efficiency.

\section{Conclusion}

Prioritising small businesses, especially retailers, in South Africa forms an important theme in small business literature and empirical findings, as well as in policy documents. The cardinal role of supply chain management skills in small business success forms the driving force behind empowering small business owners or managers. A small business' competitive strategy determines its orientation towards costefficiency and responsiveness. Once owners or managers have decided on a competitive strategy, they should align their supply chain strategy and supply chain drivers accordingly. The lack of mentorship and training in supply chain management skills motivated this literature review to present such owners or managers with a set of general guidelines when deciding on the logistical issues of facilities, inventory and transportation. Therefore, this article provides guidelines from literature that small business retailers can use in managing their logistical supply chain drivers to be aligned with the orientation of their selected supply chain strategy in terms of responsiveness and cost-efficiency.

Retailers with a supply chain strategy orientated towards responsiveness should carry excess inventory and order inventory on a frequent basis to ensure that customer demand can be met. These responsive retailers should preferably be located close to their customers and strive to provide customers with a seamless in-store experience. The availability of road transportation as the main option of transportation is to the advantage of responsive small retailers as this increases flexibility and reduces lead times. On the other hand, retailers with a supply chain strategy orientated towards cost-efficiency should reorder inventory in large quantities to gain the advantage of economies of scale, as well as economies of distance when transporting inventory via road. These cost-efficient retailers do not hold excess inventory and consequently do not require additional storage space. Their stores are usually located further away from customers where costs such as rent are lower than those locations situated closer to customers.

\section{Acknowledgements Competing interests}

The authors declare that they have no financial or personal relationships that may have inappropriately influenced them in writing this article.

\section{Authors' contributions}

T.E. is a lecturer at the University of South Africa. This article is based on her Master's dissertation completed in 2017. J.O.C. was the supervisor of T.E.'s Master's dissertation and contributed to the conceptualisation of the article, as well as analysing and recording literature from the dissertation.

\section{References}

Abanis, T., Sunday, A., Burani, A. \& Eliabu, B., 2013, 'Financial management practices in small and medium enterprises in selected districts in Western Uganda', Research Journal of Finance and Accounting 4(2), 29-42.

Abor, J. \& Quartey, P., 2010, 'Issues in SME development in Ghana and South Africa', International Research Journal of Finance and Economics 39, 218-228.

Alhabeeb, M.J., 2015, Entrepreneurial finance - Fundamentals of financial planning and management for small businesses, John Wiley \& Sons, Hoboken, NJ.

Allen, K.R., 2012, New venture creation, 6th edn., South-Western Cengage Learning, Mason, $\mathrm{OH}$.

Aykan, E., Aksoylu, S. \& Sönmez, E., 2013, 'Effects of support programs on corporate strategies of small and medium-sized enterprises', Procedia - Social and Behavioural Sciences 99, 938-946. https://doi.org/10.1016/j.sbspro.2013.10.567

Badenhorst-Weiss, J.A., Van Biljon, E.H.B. \& Ambe, I.M., 2017, Supply chain management: A balanced approach, Van Schaik, Pretoria.

Baily, P., Farmer, D., Crocker, B., Jessop, D. \& Jones, D., 2008, Procurement principles and management, 10th edn., Financial Times, Prentice Hall, Harlow.

Baker, P. \& Canessa, M., 2009, 'Warehouse design: A structured approach', European Journal of Operational Research 193(2), 425-436. https://doi.org/10.1016/j. ejor.2007.11.045

Banker, R.D., Mashruwala, R. \& Tripathy, A., 2014, 'Does a differentiation strategy lead to more sustainable financial performance than a cost strategy?', Management Decisions 52(5), 872-896. https://doi.org/10.1108/MD-05-2013-0282

Barloworld Logistics, 2016, Supply chain foresight. Navigating smart. Drive tomorrow's change today, viewed 17 July 2016, from http://www.barloworld-logistics.com/ navigating-smart/

Berman, O. \& Sapna, K.P., 2001, 'Optimal control of service for facilities holding inventory', Computers \& Operations Research 28(5), 429-441. https://doi.org/ 10.1016/S0305-0548(99)00128-8

Borella, M.R.C. \& Padula, A.D., 2010, 'Alignment between the supply, manufacturing and distribution strategies and the business strategy', Journal of Operations and Supply Chain Management 3(2), 44-60.

Bowersox, D.J., Closs, D.J., Cooper, M.B. \& Bowersox, J.C., 2013, Supply chain logistics management, 4th edn., McGraw-Hill Irwin, New York.

Box, T.M. \& Miller, W.D., 2011, 'Small-firm competitive strategy', Academy of Strategic Management 10(1), 55-60.

Chopra, S. \& Meindl, P., 2016, Supply chain management: Strategy, planning, and operation, 6th edn., Pearson, Harlow. 
Choto, P., Tengeh, R.K. \& Iwu, C.G., 2014, 'Daring to survive or to grow? The growth aspirations and challenges of survivalist entrepreneurs in South Africa', Environmental Economics 7(4), 93-101.

Christopher, M. \& Gattorna, J., 2005, 'Supply chain cost management and value-based pricing', Industrial Marketing Management 34(2), 115-121. https://doi.org/ 10.1016/j.indmarman.2004.07.016

Coyle, J.J., Langley, C.J., Novack, B.J. \& Gibson, B.J., 2013, Managing supply chains. A logistics approach, 9th edn., South-Western/Cengage, Mason, $\mathrm{OH}$.

CSIR, 2014, 10th annual state of logistics survey for South Africa 2013, viewed 15 November 2014, from http://www.csir.co.za/sol/

De Villiers, G., Nieman, G.H. \& Niemann, W., 2017, Strategic logistics management: A supply chain management approach, 2 nd edn., Van Schaik, Pretoria.

Ehlers, T. \& Lazenby, K., 2010, Strategic management-Southern African concepts and cases, 3rd edn., Van Schaik, Pretoria.

Ehrenthal, J.C.F., Honhon, D. \& Van Woensel, T., 2014, 'Demand seasonality in retail inventory management', European Journal of Operational Research 238(2), 527-539. https://doi.org/10.1016/j.ejor.2014.03.030

Erasmus, B.J., Strydom, J.W. \& Rudansky-Kloppers, S., 2013, Introduction to business management, 9th edn., Oxford, Cape Town.

Fawcett, S.E., Ellram, L.M. \& Ogden, J.A., 2007, Supply chain management: From vision to implementation, 1st edn., Pearson, Upper Saddle River, NJ.

Fernie, J. \& Sparks, L., 2014, Logistics and retail management, 4th edn., Kogan Page, London.

Fisher, M.L., 1997, 'What is the right supply chain for your product?', Harvard Business Review, March-April, 105-116.

Gattorna, J., 2003, Gower handbook of supply chain management, Gower, Hants, UK.

Gattorna, J., 2010, Dynamic supply chains. Delivering value through people, 2nd edn., Financial Times, Prentice Hall, Harlow, UK.

Gauteng Quarterly Bulletin, 2012, The retail industry on the rise in South Africa, viewed 20 December 2015, from http://www.treasury.gpg.gov.za/Documents/ QB1\%20The\%20Retail\%20Industry\%20on\%20the\%20Rise.pdf

Gligor, D.M. \& Holcomb, M.C., 2012, 'Understanding the role of logistics capabilities in achieving supply chain agility: A systematic literature review', Supply Chain Management: An International Journal 17(4), 438-453. https://doi.org/10.1108/ Management: An Intern

Goldsby, T.J., Iyengar, D. \& Rao, S., 2014, The definitive guide to transportation: Principles, strategies, and decisions for the effective flow of goods and services, Principles, strategies, and decisions for the
1 st edn., Pearson, Upper Saddle River, NJ.

Graungaard Pedersen, S., Zachariassen, F. \& Stentoft Arlbjørn, J., 2012, 'Centralisation vs. de-centralisation of warehousing: A small and medium-sized enterprise
perspective', Journal of Small Business and Enterprise Development 19(2), 352pers. https://doi.org/10.1108/14626001211223946
369

Havenga, J. \& Simpson, Z., 2014, 'Reducing national freight logistics costs risk in a highoil-price environment: A South African case study', The International Journal of Logistics Management 25(1), 35-53. https://doi.org/10.1108/IJLM-11-2012-0133

Hatten, T.S., 2012, Principles of small business management, 5th edn., South-Western/ Cengage, Florence, SC

Hines, T., 2013, Supply chain strategies: Demand driven and customer focused, 2nd edn., Routledge, New York.

Hoejmose, S., Brammer, S. \& Millington, A., 2012, 'An empirical examination of the relationship between business strategy and socially responsible supply chain management', International Journal of Operations \& Production Management 33(5), 589-621. https://doi.org/10.1108/01443571311322733

Holter, A.R., Grant, D.B., Ritchie, J. \& Shaw, N., 2008, 'A framework for purchasing transport services in small and medium size enterprises', International Journal of Physical Distribution \& Logistics Management 38(1), 21-38. https://doi.org/ Physical Distribution \& Logistics
$10.1108 / 09600030810857193$

Hong, P. \& Jeong, J., 2006, 'Supply chain management practices of SMEs: From a business growth perspective', Journal of Enterprise Information Management19(3) 292-302. https://doi.org/10.1108/17410390610658478

Horn, G., Badenhorst-Weiss, J.A., Cook G., Heckroodt, S., Howell, J., Phume, T. et al., 2014, Supply chain management. A logistics approach, Oxford, Cape Town.

Hsieh, Y.H. \& Chen, H.M., 2011, 'Strategic fit among business competitive strategy, human resource strategy, and reward system', Academy of Strategic Management Journal 10(2), 11-32.

Hugo, W.M.J. \& Badenhorst-Weiss, J.A., 2011, Purchasing \& supply management, 6th edn., Van Schaik, Pretoria.

Hugos, M., 2006, Essentials of supply chain management, Wiley, Hoboken, NJ.

Islam, D.M.Z., Meier, J.F., Aditjandra, P.T., Zunder, T.H. \& Pace, G., 2013, 'Logistics and supply chain management', Research in Transportation Economics 41(1), 3-16. supply chain management', Research in Transp
https://doi.org/10.1016/j.retrec.2012.10.006

Johnson, F. \& Ruankaew, T., 2017, 'A study of inventory control systems by Jamaican SMEs in retail and manufacturing/distribution industries', International Journal of Business and Management 12(8), 1. https://doi.org/10.5539/ijbm.v12n8p1

Jooste, C.J., Strydom, J.W., Berndt, A. \& Du Plessis, P.J. (eds.), 2012, Applied strategic marketing, 4th edn., Pearson, Cape Town.

Kamath, N.B. \& Roy, R., 2007, 'Capacity augmentation of a supply chain for a shor lifecycle product: A system dynamics framework', European Journal of Operational Research 179(2), 334-351. https://doi.org/10.1016/j.ejor.2006.03.045

Katz, J.A. \& Green, R.P., 2012, Entrepreneurial small businesses, 3rd edn., McGraw-Hill, New York.
Kesavan, S. \& Kushwaha, T., 2014, 'Differences in retail inventory investment behavior during macroeconomic shocks: Role of service level', Production and Operations Management 23(12), 2118-2136. https://doi.org/10.1111/poms.12048

Kotler, P., Burton, S., Deans, K., Brown, L. \& Armstrong, G., 2013, Marketing, 9th edn., Pearson, Frenchs Forest, Australia.

Lawrence, A.S., Sivakumar, B. \& Arivarignan, G., 2013, 'A perishable inventory system with service facility and finite source', Applied Mathematical Modelling 37(7), 4771-4786. https://doi.org/10.1016/j.apm.2012.09.018

Lazenby, K., 2014, The strategic management process: A South African perspective, 1st edn., Van Schaik, Pretoria.

Lebusa, M.J., 2013, 'The prospects of making small retail outlets in the townships aggressively competitive', The Southern African Journal of Entrepreneurship and Small Business Management 6, 75-86. https://doi.org/10.4102/sajesbm.v6i1.34

Lee, H.L., 2002, 'Aligning supply chain strategies with product uncertainties', California Management Review 44(3), 105-119. https://doi.org/10.2307/41166135

Leitner, K.H. \& Güldenberg, S., 2010, 'Generic strategies and firm performance in SMEs: A longitudinal study of Austrian SMEs', Small Business Economics 35(2), SMEs: A longitudinal study of Austrian SMEs', Small Busi

Li \& Fung Research Centre, 2008, China's logistics industry. 2007-2008 China distributions and trading, viewed 18 July 2015, from http://www.funggroup.com/ eng/knowledge/research/china_dis_issue53.pdf

Ligthelm, A.A., 2008, 'The impact of shopping mall development on small township retailers', South African Journal of Economic and Management Sciences 11(1), 37-53. https://doi.org/10.4102/sajems.v11i1.376

Liu, Z., Chen, L., Li, L. \& Zhai, X., 2014, 'Risk hedging in a supply chain: Option vs. price discount', International Journal of Production Economics151, 112-120. https:// doi.org/10.1016/j.ijpe.2014.01.019

Malebana, M.J. \& Swanepoel, E., 2015, 'Graduate entrepreneurial intentions in the rural provinces of South Africa', Southern African Business Review 19(1), 89-111.

Mariotti, S. \& Glackin, C., 2012, Entrepreneurship \& small business management, Pearson, Upper Saddle River, NJ.

Matabooe, M.J., Venter, E. \& Rootman, C., 2016, 'Understanding relational conditions necessary for effective mentoring of black-owned small businesses: A South African perspective', Acta Commercii 16(1), 1-11. https://doi.org/10.4102/ac. v16i1.327

Mbonyane, B. \& Ladzani, W., 2011, 'Factors that hinder the growth of small businesses in South African townships', European Business Review 23(6), 550-560. https:// doi.org/10.1108/09555341111175390

Merschmann, U. \& Thonemann, U.W., 2011, 'Supply chain flexibility, uncertainty and firm performance: An empirical analysis of German manufacturing firms', International Journal of Production Economics 130(1), 43-53. https://doi. International Journal of Product
org/10.1016/j.ijpe.2010.10.013

Monczka, R.M., Handfield, R.B., Giunipero, L.C. \& Patterson, J.L., 2016, Purchasing and supply chain management, 6th edn., Cengage, Boston, MA.

Morita, M., Machuca, J.A., De los Ríos, J.L.P. \& Flynn, E.J., 2015, 'Effects of supply chain strategy on product development', 22nd International Annual European Operations Management Association Conference (EurOMA), Switzerland, viewed 20 December 2015, from http://www.euroma2015.org/euromapapers/papers/ SCM-42_33226.pdf

Nichols, J., 2010, Transport and logistics companies for small businesses, viewed 13 June 2015, from http://www.business.com/inventory-management/ transportation-and-logistics companies-for-small-business/

Nkosi, E., Bounds, M. \& Goldman, G., 2013, 'Skills required for the black-owned smal enterprise in Soweto', Acta Commercii 13(1), 1-10. https://doi.org/10.4102/ac. v13i1.186

Orfanos, V., Mylonakis, J. \& Evripiotis, M., 2010, 'An evaluation of logistics determinates, business relationships and firms characteristics of the Greek smal and medium enterprises', International Journal of Marketing Studies 2(2), 21-33. https://doi.org/10.5539/ijms.v2n2p21

Parnell, A.A., 2013, 'Uncertainty, generic strategy, strategic clarity, and performance of retail SMEs in Peru, Argentina, and the United States', Journal of Small Business Management 51(2), 215-234. https://doi.org/10.1111/jsbm.12010

Petty, J.W., Palich, L.E., Hoy, F. \& Longenecker, J.G., 2012, Managing small business: An entrepreneurial emphasis, 16th edn., South-Western/Cengage, Mason, $\mathrm{OH}$.

Pienaar, W.J. \& Vogt, J.J., 2012, Business logistics management: A value chain perspective, 4th edn., Oxford, Cape Town.

Porter, M., 1985, Competitive advantage: Creating and sustaining superior performance, The Free Press, New York.

PriceWaterhouseCoopers, 2012, South African retail and consumer products outlook 2012-2016, Cape Town, viewed 06 June 2017, from https://www.pwc.co.za/en/ assets/pdf/retail-and-consumer-products-outlook-2012-2016.pdf

Prinsloo, D.A., 2016. Retail trends in a very dynamic South African market, Urban Studies, viewed 30 October 2016, from http://www.urbanstudies.co.za/retailtrends-in-a-very-dynamic-south-african-market/

Qrunfleh, S. \& Tarafdar, M., 2013, 'Lean and agile supply chain strategies and supply chain responsiveness: The role of strategic supplier partnership and postponement', Supply Chain Management: An International Journal 18(6), 571-582. https://doi.org/10.1108/SCM-01-2013-0015

Richards, G., 2014, Warehouse management: A complete guide to improving efficiency and minimizing costs in the modern warehouse, 2 nd edn., Kogan Page, London.

Salavou, H.E., 2015, 'Competitive strategies and their shift to the future', European Business Review 27(1), 80-99. https://doi.org/10.1108/EBR-04-2013-0073 
Scarborough, N.M., 2011, Essentials of entrepreneurship and small business management, 6th edn., Pearson Prentice Hall, Upper Saddle River, NJ.

Schmitt, A.J., Sun, S.A., Snyder, L.V. \& Shen, Z.J.M., 2015, 'Centralization versus decentralization: Risk pooling, risk diversification, and supply chain disruptions', Omega 52, 201-212. https://doi.org/10.1016/j.omega.2014.06.002

Simon, A.T., Serio, L.C.D., Pires, S.R.I. \& Martins, G.S., 2015, 'Evaluating supply chain management: A methodology based on a theoretical model', Revista de Administração Contemporânea 19(1), 26-44. https://doi.org/10.1590/1982-7849rac20151169

Soinio, J., Tanskanen, K. \& Finne, M., 2012, 'How logistics-service providers can develop value-added services for SMEs: A dyadic perspective', The International Journal of Logistics 23(1), 31-49. https://doi.org/10.1108/09574091211226911

Soni, G. \& Kodali, R., 2011, 'The strategic fit between "competitive strategy" and "supply chain strategy" in Indian manufacturing industry: An empirical approach', Measurin Business Excellence 15(2), 70-89. https://doi.org/10.1108/13683041111131637

South Africa. National Planning Commission, 2012, National development plan 2030. Our future - Make it work, The Presidency, Pretoria.

Statistics South Africa, 2016, Quarterly financial statistics, viewed 20 December 2016 from http://www.statssa.gov.za/publications/P0044.pdf

Stellenbosch University, 2015, Logistics barometer South Africa, viewed 21 Septembe 2015, from http://www.sun.ac.za/english/faculty/economy/logistics/Documents/ Logistics\%20Barometer/Logistics\%20Barometer\%202015.pdf

Stokes, D. \& Wilson, N., 2010, Small business management and entrepreneurship, 6th edn., Cengage Learning EMEA, UK.

Storsjö, I., Martins, A.L. \& Zanoni, S., 2015, 'Leanness and agility in the judicial supply chain', 22nd International Annual European Operations Management Association Conference (EurOMA), Switzerland, viewed 20 December 2015, from http://www. euroma2015.org/euromapapers/papers/PUB-01_32995.pdf

Strydom, J.W., 2015, 'David against Goliath: Predicting the survival of formal small businesses in Soweto', International Business \& Economics Research Journal 14(3) 463-476. https://doi.org/10.19030/iber.v14i3.9210
Teeratansirikool, L., Siengthai, S., Badir, Y. \& Charoenngam, C., 2013, 'Competitive strategies and firm performance: The mediating role of performance strategies and firm performance: The mediating role of performance Management 62(2), 168-184. https://doi.org/10.1108/17410401311295722

Töyli, J., Häkkinen, L., Ojala, L. \& Naula, T., 2008, 'Logistics and financial performance: An analysis of 424 Finnish small and medium-sized enterprises', International Journal of Physical Distribution \& Logistics Management 38(1), 57-80. https://doi. org/10.1108/09600030810857210

Van Eeden, S., Viviers, S. \& Venter, D., 2003, 'A comparative study of selected problems encountered by small businesses in the Nelson Mandela, Cape Town and Egoll . Management Scientists 12(3), 13-23.

West, D., Ford, J. \& Ibrahim, E., 2015, Strategic marketing: Creating competitive advantage, 3rd edn., Oxford, Oxford.

Wieland, A. \& Wallenburg, C.M., 2012, 'Dealing with supply chain risks: Linking risk management practices and strategies to performance', International Journal of Physical Distribution \& Logistics Management 42(10), 887-905. https://doi.org/ 10.1108/09600031211281411

Wisner, J.D., Tan, K.C. \& Leong, G.K., 2016, Supply chain management: A balanced approach, 4th edn., South-Western, Boston, MA.

Yu, W. \& Egbelu, P.J., 2013, 'Development of dispatching strategy for inbound and outbound trucks in cross docking system', Journal of the Korea Safety Management and Science 15(2), 167-184. https://doi.org/10.12812/ksms 2013.15.2.167

Zowada, K., 2013, 'Business cooperation of logistic companies with small and medium enterprises - Research report', Journal of Economics \& Management $12,112-120$

Zuraimi, A.A., Yaacob, M.R. \& Ibrahim, M.D., 2013, 'Logistics development in Malaysia East coast region: Infrastructure, constraints and challenges', International Journal of Trade, Economics and Finance 4(5), 325-330. https://doi.org/10.7763/ IJTEF.2013.V4.310 